\title{
The Integration of Culturally Responsive Transformative Teaching to Enhance Student Cultural Identity in the Chemistry Classroom
}

\author{
Yuli Rahmawati", Achmad Ridwan, Ucu Cahyana, Dina Febriana \\ Department of Chemistry Education, Universitas Negeri Jakarta, Indonesia
}

Received November 17, 2019; Revised December 14, 2019; Accepted December 25, 2019

Copyright $\mathrm{O} 2020$ by authors, all rights reserved. Authors agree that this article remains permanently open access under the terms of the Creative Commons Attribution License 4.0 International License

\begin{abstract}
This study explored how the integration of culturally responsive transformative teaching (CRTT) approach was applied to chemistry learning with the aim of enhancing student cultural identity. The study consisted of five phases: 1) self-identification, 2) cultural understanding, 3) collaboration, 4) critical reflection, and 5) transformative construction [34]. A qualitative methodology was employed with multiple data collection samples through classroom observations, reflective journals, student interviews, and a concept test. The integration of CRTT was implemented in a chemistry classroom at a public secondary school with 35 year 10 students studying the topic of electrolyte and non-electrolyte solutions. The data was analyzed using the basic principles of cultural identity categories. The results of the study show that the integration of CRTT helped students enhance their cultural identity and nationalism, awareness of cultural differences, and their learning about cultural identity development. The integration of CRTT is relevant to the aims of the Indonesia curriculum which is focused on developing student character and cultural identity.
\end{abstract}

Keywords Chemistry Learning, CRTT, Students' Cultural Identity

\section{Introduction}

Indonesia, the world's largest archipelagic state, is comprised of 17.500 islands and has a population of over 200 million people, many with distinct ethnicities, such as Javanese, Sundanese, Madurese, Costal Malays, and many others [1]. In the classroom, cultural differences affect values and the ways students think and interact with each other and with teachers. According to [2], a teacher's cultural background largely determines the learning conditions and processes and how meaningful content is for the students. During the learning process, teachers must pay attention to differences in cultural backgrounds and the characteristics of students with the aim of helping them construct their knowledge. According to [3], in the process of constructing knowledge, students are influenced by a number of factors such as gender, socioeconomic status, ethnicity or geography, age, learning styles, religion, racial identity, language, and social behavior. These factors affect the student's mindset by indirectly constructing the initial knowledge they bring into the classroom.

Indonesian teachers currently use what is known as Curriculum 2013 which was developed using an educational philosophy aimed at embedding the nation's culture into the curriculum as a critical focus in the present and for the future. In addition, Curriculum 2013 adheres to learning practices that recognize students' direct experiences in accordance with their background, characteristics, and initial abilities [4]. This learning practice was developed to overcome less meaningful learning in the classroom, such as a lack of interest by students in the learning process. Curriculum 2013 was developed to help shape 18 identified character values of religiosity, honesty, tolerance, discipline, hard work, creativity, independence, democratic thinking, curiosity, nationalism, love of country, appreciation of achievement, communicative competence, love of peace, love of reading, care for the environment, social care and responsibility [5]. However, these characters are increasingly difficult to find in the younger generations due to the impact of globalization on the loss of culture in Indonesian communities [6]. Learning by paying attention to the different backgrounds students come from can help teachers understand the diverse cultural characteristics students bring to the classroom and how varying their learning approaches can help overcome any difficulties 
that may occur.

One approach that can help teachers integrate culture into the classroom is CRT which uses the student's cultural references for learning engagement [7]. According to [8], CRT uses diverse cultural knowledge, previous experience, and student performance leading to more meaningful learning. [7] claims that the CRT ensures students perform well academically whilst encouraging them to think critically about their current culture and how they can maintain their cultural identity. The CRTT approach has been developed by integrating CRT principles which allows students to explore the different cultures in Indonesia and how cultural identity impacts in relation to their daily lives [9]. Students also learn to respect and empathize with other students based on the cultural background of each region. Research on the integrating CRT principles has been widely applied to teaching and learning, including with teachers who apply CRT effectively because they are able to use their culture as a reference point to contextualize the content [10].

Chemistry is a branch of natural science that studies the changes in matter, interactions, and the energy related or caused by the changes of nature [11]. When learning chemistry, students are expected to understand chemistry concepts in order to solve problems by building their individual knowledge $[12,13]$. However, research shows that students often experience difficulties with chemistry because of their inability to visualize the structure and process at the submicroscopic level and to connect it with the other chemical representative levels [14]. Chemistry learning only becomes intact and meaningful if it is associated with the three levels of chemistry learning characteristics, namely macroscopic, microscopic and symbolic $[15,16]$.

In Indonesia, an overloaded curriculum, the abstract concept of chemistry unrelated to students' everyday lives, and learning directed towards student's memorization of concepts all contribute to ineffective chemistry education [17]. The current curriculum expects students to not only understand chemistry concepts, but also to relate the concepts to real-world situations. To achieve these goals, chemistry learning must develop a student's ability to solve problems in a more meaningful way in relation to the student's own cultural identity. This change in focus from teacher as content deliverer to teacher as facilitator demands a more creative approach that contextualizes the learning so that students can relate the content to real-life situations.

Therefore, this study focuses on the integration of CRTT in chemistry classroom to enhance students' cultural identity. The CRTT approach consists of five phases: self-identification, cultural understanding, collaboration, critical reflection, and transformative construction [9]. A previous study that explored in the concept of electrolyte and non-electrolyte solutions in year-10 chemistry classrooms using the CRTT approach showed that students were empowered to learn chemistry [9].

\section{Research Methodology}

The study used qualitative analysis of multiple data collection methods consisting of reflective journals, classroom observations, interviews, fieldnotes, and concept tests. Qualitative data were collected to inform how the integration of CRTT could enhenced students' cultural identity in learning electrolyte and non-electrolyte topics. The study consisted of three stages, namely the preliminary stage, the implementation stage, and the final stage that were conducted five times across a three week period. The preliminary stage included an initial classroom analysis, preparation of learning plans, guidelines for written reflections, fieldnotes, and preparation of a student interview question guide. The second stage involved implementing CRTT approach in the five learning stages of self-identification, cultural understanding, collaboration, critical reflective thinking, and transformative construction. The final stage included student interviews and data processing.

\subsection{Participant}

Thirty five students from tenth grade of one of public senior high school in West Java Province well-known as SMAN 1 Cikembar Sukabumi participated in the study. The remaining 35 (10 males and 20 females) students responses were analyzed. The largest ethnic group in West Java is Sundanese, in this study $95 \%$ of the students is Sundanese and rest of 5\% is come from outside Sukabumi (non-Sundanese).

\subsection{Data Collection}

The multiple data collection methods used in the study consisted of classroom observations, a reflective journal, fieldnotes, semi-structured interviews, and a concept tests. In the preliminary phase, the chemistry teacher was observed and the cultural identities of the students were recorded. In the implementation phase, the researcher gathered data through classroom observations, reflective journals and fieldnotes. The reflective journal required students to reflect on how they were feeling and thinking about the learning activities and experience and how they responded using the integration of CRTT. Field notes included observations on how the integration CRTT was applied and how the students responded. Observations were written descriptions recorded by the researcher and two observers who noted students' identity development during learning process in the classroom. In the last implementation phase, the researcher interviewed students using an open-ended semi-structured interview and concept test aimed at revealing the students' feelings, 
thinking, and their experience in relation to the integration of CRTT, and their identity development. The interviews were conducted outside normal class activities for $\pm 10-15$ minutes per student using voice recorders.

\subsection{Data Analysis}

Qualitative data analysis was performed interactively and continuously until completion as recommended by [18] by proceeding through the three stages of data reduction, data presentation, and verification and conclusions. Reduction was done by coding the data that had been collected through classroom observations, reflective journals, field notes, interviews, and the concept test, focusing on matters relating to the research. During reduction, the researcher summarized and retrieved the data to analyze the application of the stages of learning in the integration of CRTT. The development of student cultural identity was then analyzed and irrelevant which were unrelated to research questions were discarded. After reducing the data the next step involved presenting the data. Presentation of data was done in the form of student data coding tables. The third step in the process [18], drawing conclusions and verification, was then undertaken. The

verification process in this study was carried out continuously throughout the process. During the stage of drawing conclusions, researchers also analyzed students' cultural identity that emerged through CRTT approach.

\section{Result and Discussion}

\subsection{The Integration of CRTT in Chemistry Learning}

The integration of CRTT approach in applies the principle of CRT [19] which consist of five categories: content integration, facilitating knowledge construction, prejudice reduction, social justice, and academic development. CRTT [9] consists of five stages, namely: self-identification, cultural understanding, collaboration, critical reflective thinking and transformative construction. The integration of CRTT learning stages is shown in the picture below.

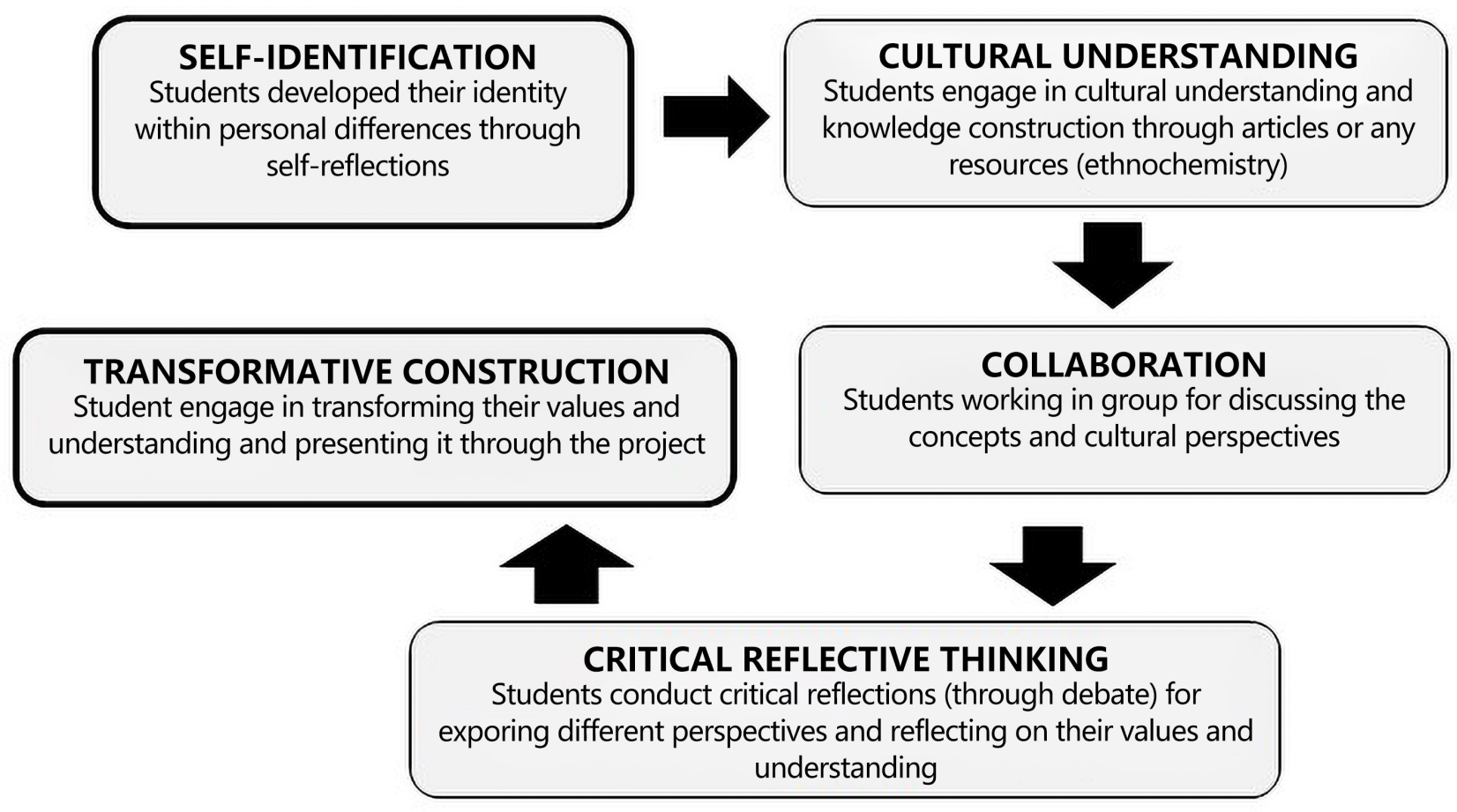

Figure 1. The Learning Stages of CRT and Ethnochemistry Integration 


\subsubsection{Self-Identification}

Self-identification is the first step in the learning process where the diverse backgrounds of students are explored. According to [9], self-identification is the stage where students identify their cultural differences and explore the limits placed on them by their identity. At this stage, students write down their cultural origins, characteristics, and learning style by filling in the questionnaire. The self-identification questionaire showed that $95 \%$ of students werevborn in Sukabumi, West Java while the other $5 \%$ were born in Jakarta and other cities. The results of students' learning style are as follows:

Table 1. Results of Kolb's learning style questionnaire

\begin{tabular}{|c|c|c|c|c|}
\hline \multirow{2}{*}{$\begin{array}{c}\text { Learning } \\
\text { Style }\end{array}$} & Accommodator & Diverger & Assimilator & Coverger \\
\cline { 2 - 5 } Gender & 5 & 20 & 5 & 5 \\
\cline { 2 - 5 } & Male & Female & - & - \\
\hline \multirow{2}{*}{ Ethnic } & 10 & 25 & - & - \\
\cline { 2 - 5 } & Sundanese & Others & - & - \\
\hline
\end{tabular}

The integration of CRTT in chemistry learning helps create a positive student response because learning chemistry associated with culture is a new initiative that is expected to increase the student's love of homeland for students. This is evidenced by the following interview results.

"Learning is exciting and different from usual, I am happy learning is associated with our daily lives and culture"

(Interview: Student 4, 7 February 2018)

"At first I was confused about learning related to culture, how chemistry is associated with culture, but in fact the learning became exciting"
(Interview: Student 24, 7 February 2018)

Based on the students' responses, the integration of CRT and ethnochemistry is very beneficial for students because it connects chemistry with their daily lives. According to [20] CRT links the concept of learning to the students' daily lives by using relevant examples. CRTT integrates culture into the learning process to create positive relationships between teachers and students. Teachers can then provide more accurate academic targets to support individual students' learning achievement. According to [21], it is important to establish good relations between teachers and students in the classroom. A warm relationship between the teacher and students can motivate students and encourage better communication between students.

\subsubsection{Cultural Understanding}

During the cultural understanding stage, students engage in knowledge construction through the use of articles and other resources related to ethnochemistry [9] and cultural understanding. This stage refers to the CRT phase [19] of Facilitating Knowledge Construction where the role of the teacher is to facilitate students ability to build their knowledge. Teachers have an important role to play in helping students to construct their own knowledge. According to [19] learning through CRTT is initiated by students' initial knowledge in learning chemistry, thus making it easier for students to understand new material.

At the cultural understanding stage, learning is facilitated by integrating cultural articles related to the student's traditions or to their real life. The following table maps the relationship between ethnochemistry articles with electrolyte and non-electrolyte solution material.

Table 2. Ethnochemistry Article Summary

\begin{tabular}{|l|l|}
\hline Article & Description \\
\hline $\begin{array}{l}\text { Utilization of Ivory Coconut } \\
\text { Water in the Tingkeban Tradition } \\
\text { in West Java }\end{array}$ & $\begin{array}{l}\text { Tingkeban is one of the ceremonials performed by pregnant women. Pregnant women drink ivory } \\
\text { coconut water during pregnancy. Ivory Coconut water has almost the same ingredients and properties } \\
\text { as green coconut. Young coconut water is known to contain electrolytes such as calcium, chloride, } \\
\text { magnesium, sodium, and riboflavin. Coconut water is also useful as a natural isotonic drink because it } \\
\text { is rich of minerals and has the same electrolyte properties as the body's electrolytes. }\end{array}$ \\
\hline $\begin{array}{l}\text { Ngeyeuk Seureuh on the West } \\
\text { Java Marriage Tradition }\end{array}$ & $\begin{array}{l}\text { Ngeyeuk Seureuh is an element of a traditional wedding ceremony in West Java which gives advice on } \\
\text { living happily in a household. Temurose Betel leaf also has a high electrical conductivity, so it can } \\
\text { show that the content of solutes that are electrolyte are quite high in temurose betel leaves. }\end{array}$ \\
\hline Peuyeum: a West Java Snack & $\begin{array}{l}\text { Peuyeum is an original food from the province of West Java. Peuyeum is made from cassava by the } \\
\text { yeast of Saccharomyces cerevisiae. Alcohol is obtained by fermenting carbohydrates from yeast. } \\
\text { According to Irianto (2006) alcohol is the most common solvent and basic material used in } \\
\text { laboratories and the chemical industry. Alcohol is also a solution that is not ionized so that it has no } \\
\text { electrical conductivity. }\end{array}$ \\
\hline $\begin{array}{l}\text { Moci: a Typical Sukabumi's } \\
\text { Cake }\end{array}$ & $\begin{array}{l}\text { In Sukabumi, a small city with cold air in West Java has a type of cake that is widely known in the } \\
\text { local community, namely Moci Cake. Sukabumi moci is packed in a bamboo basket. Each basket } \\
\text { usually consists of ten moci cakes. Amylopectin is a monomer of } \alpha \text {-glucose. In solution, glucose } \\
\text { (C6H12O6) is a solution that is not ionized so that it shows electrical conductivity. Therefore, glucose } \\
\text { solution is a non-electrolyte solution. }\end{array}$ \\
\hline
\end{tabular}


The articles discussed relate chemistry concepts to tradition, culture and/or everyday life. Articles are used as a forum for students to develop their knowledge. Ethnochemistry articles pique students interested in learning as reflected in the journal and interview responses below.

"In my opinion today's learning is very different from before, because it uses a new method by using articles so that all students find out about what is being discussed through the internet, books, etc."

(Reflective Journal: Student 04, 21 February 2018)

"I am very happy to study, it turns out that my local specialties related to chemistry, it is amazing when we know the chemical content of what we eat everyday. The article is very useful"

(Interview: Student 12, February 21, 2018)

The reflective journals and interviews show that learning with culturally relevant articles attracts students' attention when they can connect chemical materials to their daily lives making it easier for them to understand the material presented. According to [8] the use of cultural knowledge and previous experiences makes learning more relevant and effective for students to construct new knowledge, making it more likely that students will become involved in the learning process.

\subsubsection{Collaboration}

The collaboration stage is where students work in groups to discuss cultural concepts and perspectives [9]. At this stage, students work together with their peers and teachers. This stage of CRTT addresses prejudice reduction which, according to [19], is a process whereby teachers take a contextual approach to the learning by using effective communication to build a positive and comfortable learning environment for all students.

In this study the teacher used various strategies such as Think Pair Share (TPS) and discussion to create a cooperative environment. A cooperative learning approach with heterogenous groups consisting of a mixture of gender, achievement levels, and also learning styles, can help create positive interactions between students regardless of their cultural background as seen by the following student responses:

"Learning by group can develop our interaction. Because in every group there must be someone who does not understand, when that's the interaction of asking, exchanging ideas to find the right answer so it will be good collaboration"

(Reflective Journal: Student 14, 21 February 2018)

"Chemistry lessons are better learn by group, because chemistry is difficult so when we find the difficult question, we can keep looking for answers together" (Interview of Student 20, February 21, 2018)
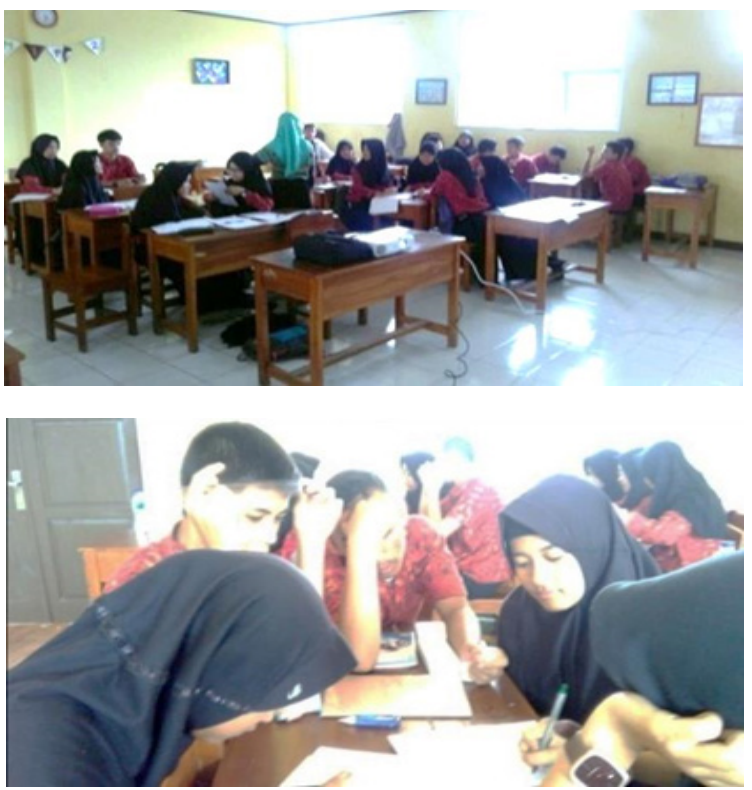

Figure 2. Student Collaboration in Chemistry Learning

Participation of all group members working together can develop tolerance and cooperative skills among students as each student provides a different perspective. Students are expected to respect and appreciate these differences. A CRTT approach frees students to achieve academic goals throughout the learning tasks whilst developing interpersonal skills that include caring for others, a sense of humanity, and a sense of mutual respect for cultural differences [8].

\subsubsection{Critical Reflective Thinking}

According to [9], students at this stage reflect critically on their values throughout the learning process to find different perspectives that challenge their understanding of concepts. This stage of CRTT is aligned to the principles of Social Justice [19] where students are encouraged to ask questions and dare to be more critical. In the learning process, students undertake a project related to the culture of Sukabumi, Sunda, or West Java regarding the application of electrolyte and non-electrolyte solutions in daily life based on relevant articles. The task expects students to explore the information and construct their understanding related to chemical materials.

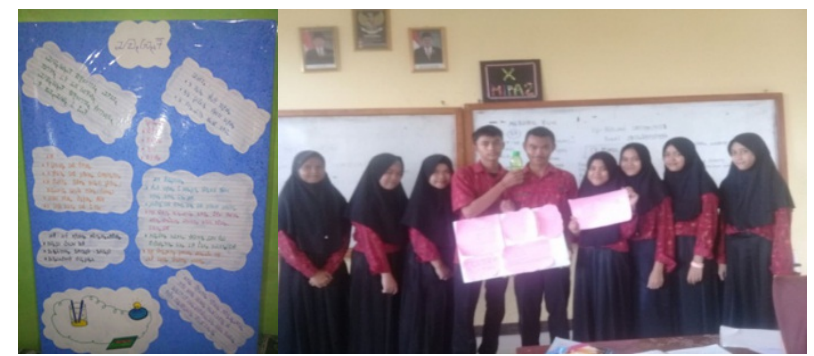

Figure 3. Students' Group Project and Presentation 
Students were able to think critically to solve the problems raised by their friends. Students' critical thinking was evident in the teacher observation sheets and diaries as follows:

"During the learning process by linking to culture, students are quite interested and critical enough to answer the questions asked by the teacher"

(Observation Sheet: 7 February 2018)

Teacher: Is there anything you want to ask again about the material that we have discussed?

Student 12: Ma'am, what if suppose we find the same electrolyte solution however in different concentration? Which one is stronger electrolyte solution?

(Fieldnotes: February 7, 2018)

In line with CRT [19] suggests that learning using the approach can help students understand, and represent information more effectively and become critical and reflective thinkers.

\subsubsection{Transformative Construction}

The last stage of integrating CRTT is transformative construction where learners change their values and understanding [9]. This stage is based on the teaching of [19] and provides opportunities for students to achieve academic goals as well as developing cultural awareness and respect for differences in collaboration with others. Students recorded the changes in the learning process as follows:

"Studying with CRTT makes me feel learning chemistry more easy, this learning makes me know more about chemistry that is linked to my own culture and life"

(Interview: Student 11, 7 March 2018)

"I feel better after studying chemistry with this method, when studying there is always a new enthusiasm for continuing to study chemistry than before"

(Reflective Journal: Student 22, 7 March 2018)

Based on the interview and reflective journal shown changes occurred in the students' attitude towards learning chemistry. Moreover, their attitude changed towards learning chemistry. Students reported becoming increasingly responsible for preserving their own culture and developing a love of country, as evidenced by the following data:

"After studying today CRTT, I feel the desire to be responsible for preserving culture in my area"

(Interview: Student 18, February 21, 2018)

"... Because being associated with local culture makes me more enthusiastic in learning because I associate more local culture so I love my own nation more"

(Reflective Journal: Student 8, 21 February 2018)

Aligned with [8] belief, CRTT teaches students to understand and apply their own cultural heritage and to respect the culture of others, resulting in a heightened love of country. The results of the study indicate that students' values change where they become increasingly aware of and responsible for their culture whilst feeling more able to master the chemistry concepts.

\subsection{Students' Cultural Identity Development in Chemistry Learning}

The integration of CRTT developed students' cultural identity in chemistry learning by developing an appreciation of love of country, cultural differences, and learning identity.

\subsubsection{Cultural Identity and Nationalism}

According to [21] cultural identity is defined as both visible and invisible domains of the self that influence self-construction. They included, but are not limited to ethnicity, skin color, gender, sexual orientation, nationality, and physical and intellectual ability. Identity, according to [22], involves all factors that constitute our lives, including genetic makeup, our parents, culture, and experiences, both bad and good. [23] defines cultural identity as one's understanding of the multilayered, interdependent, and nonsynchronous interaction of social status, language, race, ethnicity, values, and behaviors that permeate and influence nearly all aspects of our lives.

Students developed their cultural identity in socio-culture contexts through the integration of CRTT by sharing beliefs, customs, relationships, and language [24]. In the following results, students show their cultural identity development.

"Today's learning is very exciting, because there is a lot to learn about local specialties. I even found out that betel leaf has an electrolyte substance"

(Interview: Student 33, 21 February 2018)

"Learning integrated CRTT made me know if coconut water is beneficial for pregnant women, and it is related to Sundanese tradition called Tingkeban"

(Reflective Journal: Student 35, 21 February 2018)

"I am very happy to study, it turns out that my local specialties related to chemistry, it is amazing when we know the chemical content of what we eat everyday. The article is very useful"

(Interview: Student 12, 21 February 2018)

The results above demonstrate that the integration of CRTT was different to the chemistry learning students were used to. Students were stimulated and motivated to learn the chemistry concepts as well as becoming motivated to identify their own cultural relationship to chemistry. This finding relates to [25] who stated that learning experiences can stimulate students' learning motivation and curiosity in order to develop their knowledge of chemistry and culture. The students looked more enthusiastic when learning chemistry linked to cultural practices. Their motivation was stimulated by integrating ethnochemistry into the learning process because it related to their everyday lives. According to [26], a positive correlation exists between learning aligned 
to cultural experiences, and the researchers identified a link between successful learners and the value of developing cultural identity in the learning process. Therefore, learning should recognize the border crossing of cultural experiences.

Learning by integrated CRTT also empower students' to love their local culture through studying articles that identify local customs and practices. Evidence of a growing national identity is demonstrated below:

"After study used CRTT, I feel that I need to be responsible for preserving my local cultures"

(Interview: Student 12, 21 February 2018)

"If it is related to local culture, it makes me more enthusiastic in learning because I can associate local culture to chemistry concept, so it makes me to love my nation more"

(Reflective Journal: Student 8, 21 February 2018)

"Learning linked to the culture makes me want to maintain that culture, especially moci"

(Interview: Student 31, 21 February 2018)

"Today's learning is cool because it associates with the traditions of the Sukabumi region. This tradition must be preserved so that it does not become extinct"

(Reflective Journal: Student 21, 21 February 2018)

The data above shows that students were stimulated through the CRTT process to develop their cultural identity. They explained how they become more engaged with Indonesian culture and loving their local culture. Today, students have limited understanding of their own culture due to the negative impact of globalization, resulting in the loss of cultural identity [22]. The CRTT approach helps developed cultural identity and makes them feel responsible to preserve their local culture. This finding is related to [27] that culturally responsive teachers not only focus on students' scores, but also on cultural identity.

\subsubsection{Awareness of Cultural Differences}

Throughout the collaboration stage of CRTT learning stages, students are able to discuss and work in groups. Working in a group encourages students to learn about different cultures by completing a project by exploring their own culture and linking it to chemistry concepts. At the same time, students are able to develop awareness of cultural differences as they work together with other students who may have different learning characteristic and cultures. The following examples reveal how students interact socially with respect for each other's perspectives:

"Today's learning is very impressive, we in terms of working groups are quite good, the other members also give opinions and respect each other's opinions"

(Reflective Journal: Student 34, 7 February 2018)

"I like learning by group, because we can interact and communicate with others. Besides that, in every group there must be someone who doesn't understand, so that's the interaction of asking questions, exchanging

\section{ideas to find the right answer"}

(Reflective Journal: Student 14, 21 February 2018)

The responses above show how students felt when cooperating with each other and their experience of learning in group. Students felt challenged by working in group, however they learned how to give and accept different opinions; a process of developing empathy and communicative competence in order to achieve successful group work. Students reflected on the positive impact of asking questions and sharing knowledge when there is a member who has difficulty understanding the concept. This finding relates to $[28,29]$ which stated that group cooperative learning in groups helps develop students' attitudes and generic skills such as communication, collaboration, and critical thinking. Students' group have arranged on the differences of gender, ethnic, learning style, and achievement levels encouraged students to build empathy to others.

The integration of CRTT helped students develop cultural awareness through cultural competency development [30] which helps students enhance their personal and interpersonal awareness through effective cross-cultural teaching.

Throughout the integration of CRTT, the teacher's role is to facilitate different learning experience and to pay attention to students' cultural differences as referred to below:

"Today's learning is very exciting for me, because I express my thoughts with a presentation in front of the class, and it was the first experience to present chemistry related to culture while studying at school"

(Interview: Student 30, 7 February 2018)

The student indicated that the teacher provided a new learning experience by integrated CRTT in chemistry learning. The integration of CRTT helped students to develop their self-confidence. The experience encouraged students to present their group's work in front of the class where in the past they would not have dared. Students appeared confident when discussing in groups by expressing opinions and conveying information to their classmates.

\subsubsection{Learning Identity}

According to [31], learning identity is at the center of learning where people see themselves as learners, seek and engage in life experiences with a learning attitude, and believe in their ability to learn. In Indonesia, the Curriculum 2013 encourages student to be active learners which is challenging for Indonesian students since they have to move from their comfort zone as passive learners to become active learners. Constructivism theory reimagines teachers as facilitators where they encourage students to construct their own knowledge by constantly assessing how the activity is helping them gain understanding [32].

By integrating of CRTT, students learn to develop their learning identity through studying their local culture. 
Students collaborate with others in order to construct their understanding of chemistry concepts. The following examples show how students developed their confidence and dared to express their opinion.

"Today's learning is exiting, I dare to ask questions and answers in presentation session in front of the class and it was the first time I did while studying at school"

(Interview: Student 30, 7 February 2018)

"It was an exited learning and makes me confident to convey the results of the discussion"

(Reflective Journal: Student 7, 7 March 2018)

"The interaction in my group was cool Ma'am, I am quite active in learning and I can express what is on my mind"

(Interview of Student 33, 7 February 2018)

The above statements show that students are engaged and motivated in chemistry learning through the integration of CRTT. This finding is related to [9] who stated that students look more enthusiastic when exploring chemistry concepts through the lens of cultural practices. Student motivation was stimulated by integrating ethnochemistry in the learning because it is related to their everyday lives.

Some students in the research study continued to focus on learning for the test and how to get a high score. However, in the integration of CRTT the students were challenged to think critically and and creatively while facing problems introduced through the articles which discussed local culture linked to chemistry concepts. Thus, the integration of CRTT drives students to not only focus on understanding the concept to get a high score in tests, but also how the concept implement in real-life situations.

"When the learning process relates to culture, students are interested and critical enough to answer questions related to the content of electrolytes in betel leaves"

(Classroom Observation: Student 3, 7 March 2018)

"I am happy when given a task by the teacher because it makes me think creatively to do the task, it such a great way to learn because it was connected the chemistry concept and our culture"

(Interview: Student 35, 7 March 2018)

The above results show that students need to build an effective chemistry understanding as related to [33] that effective understanding developed through critical thinking is important for students to retain new knowledge, as required if they are to be considered active learners.

Finally, the integration of CRTT needs to be applied in chemistry learning in order to enhance students' cultural identity. Contemporary education theory encourages students to develop conceptual understanding alongside creating links to real-life situations so that students can participate fully in society and help solve social problems related to chemistry. A previous study showed that the students faced the challenges in changing the learning focus from being exam oriented to a more collaborative and culturally appropriate methodology [34]. In this study, the teacher facilitated students towards a deeper understanding of their cultural identity. However, both teachers and students need to shift their beliefs about teaching and learning in order to create a meaningful learning environment where approaches such as CRTT can be successful.

\section{Conclusions}

The integration of CRTT in chemistry learning stimulated students to enhance their identity. This teaching approach is a new experience for students learning chemistry concepts linked to their local culture. Through the process, students were able to see the relevance and importance of chemistry in their daily lives. The study showed students developed their understanding of cultural identity and nationalism which is indicated by an increasing students' sense of responsibility to preserve their local culture. Students also developed their awareness of cultural differences indicated by the development of students' attitudes at group which arranged based on the differences of gender, ethnic, learning style, and achievement levels encouraged students to build empathy to others. The enhancement of students motivation, engagement, confidence, and dared to express their opinion in learning pointed that students learning identity has been developed. Throughout the integration of CRTT, the teacher as facilitator must pay attention to students' cultural backgrounds in order to engage students in the learning process. The integration of CRTT is also relevant to the aim of the Indonesia curriculum which is focused on building and developing students' character and cultural identity. As for the challenges faced in this study are time management, local culture related to chemistry concept, and changing learning focus from being exam oriented to meaningful learning.

\section{Acknowledgements}

We would like to thank the Ministry of Research, Technology, and Higher Education, Indonesia for the research grant, the Universitas Negeri Jakarta, and the school for their support.

\section{REFERENCES}

[1] Regional Language Network. Indonesia - People, Culture, Language, RLN East Midlands, United Kingdom, 2007.

[2] Ogunniyi, M. B. Effect of an argumentation-based course on teachers' disposition towards a science-indigenous 
knowledge curriculum, International Journal of Environmental \& Science Education, pp 159-177, 2008.

[3] Margery B. Ginsberg \& Raymond J. Wlodkowski. Diversity and Motivation: Culturally responsive teaching in college, Jossey-Bass, California: Jossey-Bass. 2009.

[4] Ministry of Education and Culture. Lampiran permendibud no 70 tahun 2013 tetang kurikulum sekolah menengah kejuruan/madrasah aliyah kejuruan, Ministry of Education and Culture, Jakarta, 2013.

[5] Ministry of Education and Culture. Pengembang Pendidikan Budaya dan Karakter Bangsa. Ministry of Education and Culture, Jakarta, 2013.

[6] Sairin, S. The Impact of Globalization on Indonesian Socio-Cultural Life, Sage journals, pp 145-158, 2004.

[7] Ladson-Billings, G. But that's just good teaching! The case for, Theory Into Practice, pp 159-165, 1995

[8] Gay G. Culturally Responsive Teaching: Theory, Practice and Research Ed Banks James A, Teachers College Press, New York, pp 1-21, 2000.

[9] Rahmawati, Y., Ridwan, A, Rahman, A., \& Kurniadewi, F. Chemistry students' identity empowerment through etnochemistry in culturally responsive transformative teaching (CRTT), Journal of Physics: Conf. Series 1156 (2019) 012032, doi:10.1088/1742-6596/1156/1/012032, pp $1-9,2019$.

[10] Sleeter, C. E. An agenda to strengthen culturally responsive pedagogy, English Teaching: Practice and Critique, pp 7-23, 2011

[11] Goldberg D. E. Schaum's Outline of Theory and Problems of Beginning Chemistry, The McGraw-Hill Companies, America, pp 1-6, 2005.

[12] Taber K. Chemical Misconceptions: Prevention, Diagnosis and Cure Ed Osborn C and Pack M, The Royal Society of Chemistry, London, p11, 2002.

[13] Koballa Jr, T. Prospective gymnasium teachers' conceptions chemistry learning and teaching, International Journal of Science Education, pp 209-224, 2010.

[14] Chittleborough, G. \& Treagust, D. F. The modelling ability of non-major chemistry students and their understanding of the sub-microscopic level, Chemistry Education Research and Practice, Vol 8, pp 274-292, 2007.

[15] Johnstone, A.H. Why science is difficult to learn: things are seldom what they seem, Journal of Computer Assisted Learning, Vol 7, pp $75-83,1991$.

[16] Garnet, P.J., Garnet, P.J. \& Hackling, M.W. Students' alternative conceptions in chemistry: a review of research and implications for teaching and learning, Studies Science Education, 25, pp 69-96, 1995.

[17] Rahmawati Y. Revealing and Reconceptualising Teaching Identity through the Landscapes of Culture, Religion, Transformative Learning, and Sustainability Education: A Transformation Journey of a Science Educator, Doctoral thesis, Curtin University, Australia, p116, 2013.

[18] Miles \& Huberman. Qualitative Data Analysis: An Expanded Sourcebook, Sage Publication, New York, 1992.

[19] Hernandez, C.M., Morales, A.R. \& Shroyer, M.G. The development of a model of culturally responsive science and mathematics teaching, Cultural Studies of Science Education, Vol 8, pp $803-820,2013$.

[20] Lickona, T. Educating for character: How our schools can teach respect and responsibility, Random house publishing, Bertelsmann, 2009.

[21] Robinson, T. L. The intersections of identity, In A. Garrod, J. V. Ward, T. L. Robinson \& R. Kilkenny (eds.), Souls looking back: Life stories of growing up Black, Routledge, New York, pp 85-98, 1999.

[22] Palmer, P. J. A Hidden Wholeness: The Journey Toward an Undivided Life, Jossey-Bass-A Wiley Imprint, San Fransisco, pp 31-50, 2004.

[23] Taylor, E. Lessons for leaders: Using critical inquiry to promote identity development, In R. H. Sheets \& E. R. Hollins (Eds.), Racial and ethnic identity in school practices: Aspects of human development, Lawrence Erlbaum Associates, Mahwah NJ, pp 231-255, 1999.

[24] Vygotsky L. S. Mind in society Ed M Cole, V John-Steiner, S Scribner and E Souberman, Harvard University Press, Cambridge, pp 79-91, 1978

[25] Rahmawati, Y., Ridwan, A., Rahman, A., \& Kurniadewi, F. Chemistry students' identity empowerment through etnochemistry in culturally responsive transformative teaching (CRTT), Journal of Physics: Conference Series, $1156012032,2019$.

[26] Altugan, A.S. The Relationship between Cultural Identity and Learning, Procedia - Social and Behavioral Sciences, Vol 186, pp 1159-1162, 2015.

[27] Griffin, R. A., \& Jackson, N. R. Privilege Monopoly: An Opportunity to Engage in Diversity Awareness, Communication Teacher, Vol 25, pp 1-6, 2011.

[28] Brown, R. Group Processes: Dynamics within and between groups 2e, Wiley-Blackwell, Oxford, 1999.

[29] Forsyth, D. R. Group Dynamics 4e: International Student Edition, Thomson Wadsworth Publishing, Belmont CA, 2006.

[30] Diller J.V. \& Moule J. Cultural Competence: A Primer for Educators Ed. Kerr M. D., Dashiell R. and Allen G., Wadsworth, Belmont CA, pp 225-30, 2005.

[31] Kolb, A.Y., \& Kolb, D.A. On Becoming a Learner: The Concept of Learning Identity. In Bamford-Rees, D., Doyle, B., Klein-Collins, B., and Wertheim, J. (Eds.). Learning Never Ends, CAEL Forum and News, Chicago, pp 5-13, 2009.

[32] Olusegun, S. Constructivism Learning Theory: A Paradigm for Teaching and Learning. IOSR Journal of Research \& Method in Education, Vol 5(6), pp 66-70, 2015.

[33] Bekoff, M. Redecorating nature: reflections on science, holism, community, humility, reconciliation, spirit, compassion, and love, Human Ecology Review, Vol 7, pp 59-67, 2000.

[34] Rahmawati, Y., Ridwan, A. \& Nurbaity. Should we learn culture in chemistry classroom: integration ethnochemistry in culturally responsive teaching, AIP Conf. Proceedings, 1868, art. no. 030009, 2017. 